\title{
HEAVY METALS IN SUBURBAN ECOSYSTEMS OF INDUSTRIAL CENTRES AND WAYS OF THEIR REDUCTION
}

\author{
NIKOLAY VLADIMIROVICH ONISTRATENKO ${ }^{1}$, ELENA ANATOLIEVNA IVANTSOVA ${ }^{1}$, \\ ANDREY ALEXANDROVICH DENYSOV ${ }^{1}$, DENYS ANATOLYEVICH SOLODOVNIKOV ${ }^{2}$
}

\begin{abstract}
${ }^{1}$ Department of Ecology and Nature Resources Management in Institute of Natural Sciences of Volgograd State University, Universitetskiy Prosp. 100, 400062, Volgograd, Russian Federation; e-mail: econecol@volsu.ru ${ }^{2}$ Department of Geography and Cartography in Institute of Natural Sciences of VolSU, Universitetskiy Prosp. 100, 400062, Volgograd, Russian Federation; e-mail: gik@volsu.ru
\end{abstract}

\begin{abstract}
Onistratenko N.V., Ivantsova E.A., Denysov A.A., Solodnikov D.A.: Heavy metals in suburban ecosystems of industrial centers and ways of their reducation. Ekológia (Bratislava), Vol. 35, No. 3, p. 205-212, 2016

Technogenic contamination of ecosystems is one of the main dangers of our time. In order to reduce the harmful effects of this contamination and to provide cost-effective and environmentally safe food production methods, we are forced to look for ways of reliable analysis of the environmental situation, the selection systems of animal husbandry and regulations for the degree of impact of pollutants on the elements of the agroecosystem. This article presents the results of studies aimed at assessing the plight of the environment of a large industrial centre, and its anthropogenic impacts on every element of the suburban ecosystems. It presents data on maintenance and migration of anthropogenous pollutants in the trophic chains of pasturable ecosystems of the suburb of Volgograd. The authors have listed the industrial enterprises as the key sources of pollution. The features of the distribution of xenobiotics in the tissues and organs of calves and heifers of different breeds were analysed in the study. Conclusions were drawn on the accumulation of heavy metals and arsenic in cattle, and the impact of this factor on the quality of production. A comparative assessment of the resistance of different breeds of cows to the action of toxicants in the environment of the Lower Volga region was carried out. Ways to decrease the impact of pollutants on the cattle organism have also been suggested. The article pays attention to the environmental pollution of the industrial centre, the influence of these processes on all elements of an ecosystem including humans, and offers ways to minimize the damage.
\end{abstract}

Key words: heavy metals, agricultural ecosystems, livestock products.

\section{Foreword}

Today, the actual limiting factor negatively influencing live organisms and the health of people and animals (including agricultural) is the environmental pollution by chemicals and the change of ecological equilibrium in the nature caused by this pollution. The main sources of food of animal origin are the agricultural ecosystems (Pen'kova et al., 2013). The use of food containing high concentration of heavy metals is extremely hazardous to the health of people. Heavy metals, in case of their migration into an agroecosystem and accumulation in 
agricultural food products, poultry farming, lactic and animal husbandry, can be the reason for food toxicosis, leading to carcinogenic and mutagen effects (Kaydulina, Pen'kova, 2011; Wanapat et al., 2013).

The Volgograd region comprises the Volgograd-city and the Volzhsky-city. The total area of the adjacent agro-industrial zone affected with pollutants created by the Volgograd region is more than 47 thousand hectares (Pen'kova et al., 2005).

At the same time, animal husbandry is a productive business in this region due to its close proximity to consumers and processing enterprises. But as it lies in the zone of influence of the industrial centres, it is exposed to high risk of pollution by various toxicants released by the industries (Belyaev, 2004; Kaydulina, Pen'kova, 2011).

\section{Material and methods}

To establish an orientation of the processes destabilizing the suburban ecosystem of Volgograd, and to identify effective ways of controlling it, an environmental monitoring of the conditions of agricultural enterprises was carried out from 2001 to 2007. This monitoring was carried out in JSC Chervlenoye and JSC Oblomovo of the Svetloyarsky area, which is the most ecologically unsuccessful southern part of a residential suburb of Volgograd. The dynamics of industrial parameters of that period are similar to the current systemic crisis caused by the global, political and economic reasons, and having a tendency to develop further (López-Alonso, 2012). Along with monitoring the livestock production, the quantitative chemical and toxicological analyses were also performed: 30 exemplars of the soil - for 26 indicators; 22 exemplars of water - for 18 indicators; 98 exemplars of forage ( 26 species of plants) - for 17 indicators; 55 exemplars of blood - for 17 measures; 18 exemplars of wool - for 40 indicators; 34 exemplars of products of slaughter - for 12 indicators; 76 exemplars of milk - for 57 indicators.

To determine the $\mathrm{pH}$, a DLC-PF potentiometer was used. Crude protein was determined by the Kjeldahl; crude fat by Soxhlet; crude fiber by Henneberg and Stohmann; carotene by colorimetric method using FEC; calcium by volumetric method; lactic, butyric and acetic acid in silage by Fliege-Lepper; heavy metals (HM) by the atomic absorption spectrophotometer 'Selmi'. HM were controlled in blood, wool, milk and products of slaughter in three dairy cattle breeds. The technological properties of milk and meat were determined in the complex analytical laboratory Volgograd State THREAD meat and dairy cattle breeding and processing of livestock products RAAS. The selection of samples of drinking water used in animal commuters, carried out according to GOST 24481-80, was analyzed by atomic adsorption method.

Chemical analysis carried out was supervised by the measurement accuracy of the operational analysis of convergence, reproducibility and accuracy $(P=0.95, n=2)$. Statistical analysis was performed using computerised software packages.

\section{Results and discussion}

The content of heavy metals (Cd, Pb, Hg, $\mathrm{Zn}, \mathrm{Cu}, \mathrm{Ni}, \mathrm{Fe})$ and as defined in system air, the soil, water, a stern, animal (cattle) (blood, indumentum, slaughter products), food of the person (milk, meat).

Researches conducted on the dynamics of pollutant in the suburban agroecosystems of Lower Volga area showed that the suburban ecosystem of Volgograd is exposed to various polluters; various heavy metals and arsenic are found in almost all its elements in excess or in maximum concentration limits.

The air of Volgograd, especially in its southern part, is oversaturated with particles of heavy metals. The level of the content of heavy metals found in free air is very high - iron (8.0), copper (0.31), manganese (0.81), and zincum (to $3.90 \mathrm{mkg} / \mathrm{m}^{3}$ ). It can be considered as 
a result of the activities of the production enterprises and industries leading to the pollution of air with their emissions: JSC Lukoil-GNP, JSC Caustic, JSC Chimprom, JSC Plant of Carbon and so forth. The secondary polluters of free air are polishing lagoons and evaporators. Along with production of dust in the air, they add pollutants to reservoirs and soil, which leads to heavy metals getting into plants.

An inspection of soils (light castanozems in a complex with solonetzic soils - from $10 \%$ to $50 \%$ ) was carried out, selecting the exemplars of soils for definition of toxicant from depth of 0-20 and 40-50 $\mathrm{cm}$ from pastures. These exemplars were selected from pastures where a large number of cattle foraged during the summer period and had forage crops which were prepared in farms, such as lucerne, barley, oats, peas, crops of long-term herbs, winter rye. Results of analyses revealed some excess of the existing marginal concentration, and more under crops of forage crops: 1.22 maximum concentration limits on zincum, 1.1 maximum concentration limits - to nickel, 1.12 - on copper.

For identification of a possibility of getting ecologically safe livestock products in the suburban Svetloyarsky area, a research at three natural sources of drinking water was conducted: Volga-Don Canal, a water intake (without cleaning the watering place, during the winter period), a pond (used as a watering place during the summer period) and an underground spring (intended as a watering place especially meant for sports horses, and sometimes used for cattle as well).

The content of zincum, nickel and copper was found to be significantly lower than maximum concentration limit in these three sources of drinking water. At the same time, a high content of chlorides (1.4-3.3 maximum concentration limits) was noted in the water, and the adverse effect of systematic use of this water by animals drinking water from these sources was visible in the health and productivity of these animals (Zelepukhin, Levahin, 2000; Thornton, 2010).

A strict definition of heavy metals and arsenic in sterns of a winter and summer diet of lactic breeds of cattle confirmed that different types of plants possess unequal ability to absorb and accumulate these heavy metals and arsenic, and also lack of a feedforward between the level of pollution and intensity of intake of metals in plants (Zelepukhin, Levahin, 2000; López-Alonso, 2012).

The greatest pollution of forages happens during the pasturable period, when the toxicants migrate into plants not only from the soil, but also from the atmosphere - in the course of respiration by a plant - through the polluted rain water and the settling dust (Kaydulina, Pen'kova, 2011; Zelepukhin, Levahin, 2000). Especially dangerous and toxiferous metals (Cd, $\mathrm{Pb}, \mathrm{Hg}$ ) and As in sterns do not exceed the established maximum concentration limits. In a grass of pastures, the content of nickel and iron, with the stipulated maximum concentration limits as 2.8 and 1.7, respectively, is exceeded. At the same time, in sterns of a winter diet in haylage, excess of iron (maximum concentration limit - 3 in a beer pellet), zincum (maximum concentration limits -2 ) and nickel ( maximum concentration limits - 1.3) is revealed.

The heavy metals getting into an animal forms biogenic complexes, mainly with proteinaceous molecules, and gets built into the metabolism of the exposed animals. Direct toxic, mutagen and carcinogenic effects of heavy metals on an organism are compensated by specific breed and individual biochemical mechanisms. 
Blood analysis of cows' first calf heifers of three lactic breeds did not reveal reliable distinctions between them, both on biochemical structure and according to the content of heavy metals and arsenic which was made of: $\mathrm{Cd}, 0.013-0.015 ; \mathrm{Hg}, 0.005-0.006$; As, 0.022-0.0025; $\mathrm{Pb}, 0.005 ; \mathrm{Zn}, 2.35-2.40 ; \mathrm{Cu}, 1.29-1.33 ; \mathrm{Ni}, 0.70-0.72 \mathrm{mg} / \mathrm{kg}$. At the same time, the concentration of iron in the blood of red steppe breed was found to be $0.67 \mathrm{mg} / \mathrm{kg}$ that is $8.8-8.2 \%$ higher than red and motley and black and motley, respectively.

The definition of maintenance of 40 elements in the indumentum of the three breeds of cows during the summer period showed that the content of majority of them corresponded to normative indexes. At the same time, an increased concentration of iron in all the breeds of cows, especially the red and motley, was noted (red and motley - 5 times higher than normative indexes, in black and motley -1.4 times, red steppe - 1.5 times). It fully corresponded to the raised content of iron in pasturable grass and drinking water.

The definition of content of heavy metals (cadmium, hydrargyrum and lead) and arsenic in products of slaughter of bull-calves showed that it is significantly lower than the maximum concentration limits in all breeds of bull-calves, and corresponded to the concentration in their diets. At the same time, the raised contents in sterns of nickel and iron influenced their localization in muscular tissue and internals of bull-calves. The content of nickel slightly exceeded maximum concentration limit in the muscular tissue (maximum concentration limit - 1.01 to 1.10) and in the hearts (red steppe bull-calves maximum concentration limits -1.69 , red and motley -1.76 , black and motley -1.79 ). The least content of nickel in the meat and internal organs was noted in the bull-calves of red steppe breed, it was observed with same regularity and in comparison to the content of iron. Copper and zincum did not exceed maximum concentration limits, both in meat and internal organs. The exception was due to the concentration of zincum in the liver at all the breeds (1.12-1.17 maximum concentration limits). The steadiest against the influence of heavy metals were bull-calves of red steppe breed; he accumulated of these heavy metals was much lesser in them, both in muscular tissue and in their internal organs.

The research of milk of three breeds of cows showed that with an identical structure of diet and water intake, the milk from the red steppe breed contained more macrocells such as phosphorus, magnesium and potassium (9.0-9.4\%, 8.0-8.9\% and $1.0-8.6 \%$, respectively) and noted in the increased concentration in sterns and pasturable vegetation of iron is 1.4 times less than the same elements in milk of cows of red-and-white breed (Table 1).

Milk of red steppe breed contained more valuable microcells like cobalt and molybdenum, selenium - by 2.0-4.0 times, iodine - by 1.6-2.1 times higher than other breeds. Dangerous (most toxiferous) metals like hydrargyrum, cadmium, lead and arsenic do not exceed maximum concentration limits and are in trace quantities in all the breeds (Table 1). The maintenance of these toxicants in the daily yield of milk differs significantly: the least content is noted in the milk of cows of red steppe breed. This breed also has the least conversion factors of heavy metals in its milk.

The greatest number of toxicants enters the cattle through forage, and its ecological safety in the conditions of a technogenezis has a special significance (Kaydulina, Pen'kova, 2011; Wanapat et al., 2013). Researches on effective use of the regional raw materials possessing the absorptive and catalytic properties are most perspective. 
$\mathrm{T} \mathrm{a} \mathrm{b} \mathrm{l} \mathrm{e} \mathrm{1.} \mathrm{The} \mathrm{concentration} \mathrm{of} \mathrm{elements} \mathrm{in} \mathrm{the} \mathrm{milk} \mathrm{of} \mathrm{three} \mathrm{breeds} \mathrm{of} \mathrm{cows} \mathrm{in} \mathrm{a} \mathrm{suburban} \mathrm{area} \mathrm{of} \mathrm{the} \mathrm{Volgograd}$ agglomeration $\mathrm{mg} / \mathrm{L}(\mathrm{n}=10)$.

\begin{tabular}{|c|c|c|c|c|}
\hline \multirow{2}{*}{ Components } & \multicolumn{3}{|c|}{ Breed cows } & \multirow{2}{*}{$\begin{array}{c}\text { Normal } \\
\text { concentration }\end{array}$} \\
\hline & Red steppe & Black and white & Red-and-white & \\
\hline \multicolumn{5}{|l|}{ Macronutrients: } \\
\hline Calcium & 1020 & 1015 & 1019 & $1100-1700$ \\
\hline Sodium & 287.3 & 300.2 & 455.1 & $450-500$ \\
\hline Phosphorus & 830.7 & 746 & 784 & $900-1100$ \\
\hline Magnesium & 125.7 & 101.1 & 111.8 & $100-150$ \\
\hline Potassium & 1311 & 1305 & 1134 & $800-1500$ \\
\hline \multicolumn{5}{|l|}{ Trace elements: } \\
\hline Iron & 1.37 & 1.63 & 6.02 & $2.7-3.0$ \\
\hline Manganese & 0.0314 & 0.048 & 0.049 & $0.2-0.4$ \\
\hline Zinc & 3.30 & 3.41 & 4.45 & $2.0-2.5$ \\
\hline Copper & 0.34 & 0.32 & 0.20 & $0.2-0.35$ \\
\hline Selenium & 0.035 & 0.017 & 0.009 & \\
\hline Molybdenum & 0.040 & 0.035 & 0.027 & \\
\hline Cobalt & 0.0018 & 0.0012 & 0.00143 & \\
\hline Iodine & 0.19 & 0.12 & 0.09 & \\
\hline Dangerous elements: & & & & MPC, $\mathrm{mg} / \mathrm{kg}$ \\
\hline Mercury & $<0.00054$ & $<0.00054$ & $<0.00054$ & 0,005 \\
\hline Cadmium & $<0.00012$ & $<0.00012$ & $<0.00012$ & 0.01 \\
\hline Arsenic & 0.0074 & 0.0092 & 0.0086 & 0.05 \\
\hline Lead & $<0.00009$ & $<0.00009$ & 0.0204 & 0.1 \\
\hline
\end{tabular}

One such regional raw material is the linen cake, which is obtained during the production of linseed oil, both for technical and food purposes. The flax seed is included into the category of nutritceuticals; it contains on its surface and in false skin cages up to $12 \%$ of mucilage, and in cotyledons $-30-40 \%$ of aliphatic oil that contains the unsaturated fatty acids linoleic, linolenic and arachidonic, united under the conditional name vitamin F. Seeds of flax are a material source for education in an organism biologically of the active materials - prostaglandinums regulating various physiological AND functions maintaining of a homeostasis. The mucilage of flax seeds has an enveloping effect on the food masses and on the mucosa of the digestive tube, protecting it from irritation, and also strengthening the peristalsis. Volgograd THREADS of meat-and-milk cattle breeding and processing of production of animal husbandry of RAAS has patented 'The way of receiving a sorbent on a vegetable basis' by I.F. Gorlov, I.N. Penkova, I.M. Osadchenko, T.T. Rivnyak (Osadchenko et al., 2004). This sorbent allows reaching the extent of cleaning of solutions of 75-91\% cadmium, copper and other heavy metals that formed the basis for its application for decreasing the maintenance of toxicants in an organism and production of cattle.

Determination of the chemical composition and nutritional value of linseed cake showed (Table 2) that it is rich in protein, and the content of essential amino acids in it is superior to watermelon and pumpkin seed oil cakes used as vegetable sorbents. 
$\mathrm{T} \mathrm{a} \mathrm{b}$ l e 2. Chemical composition and nutritive value of linseed cake.

\begin{tabular}{|c|c|c|c|c|c|c|c|c|c|c|c|}
\hline \multicolumn{12}{|c|}{ Nutrient content in \% of dry substance } \\
\hline Water & \multicolumn{2}{|c|}{ Dry matter } & \multicolumn{2}{|c|}{ Protein } & \multicolumn{2}{|c|}{ Fat } & Cellulose & Ash & \multicolumn{2}{|c|}{ Calcium } & Phosphorus \\
\hline 6.33 & \multicolumn{2}{|c|}{93.67} & \multicolumn{2}{|c|}{35.8} & \multicolumn{2}{|c|}{\begin{tabular}{l|l}
9.94 & \\
\end{tabular}} & 5.68 & 6.60 & \multicolumn{2}{|c|}{0.62} & 0.93 \\
\hline \multicolumn{12}{|c|}{ Metals, mg/kg dry matter } \\
\hline $\mathrm{Cd}$ & $\mathrm{Pb}$ & As & $\mathrm{Hg}$ & $\mathrm{Cu}$ & $\mathrm{Ni}$ & $\mathrm{Fe}$ & Co & Mo & $\mathrm{Zn}$ & $\mathrm{Mn}$ & $\mathrm{J}$ \\
\hline 0.03 & 0.1 & 0.03 & 0.01 & 22.3 & 2.3 & 45.5 & 0.3 & 0.7 & 64.3 & 4.48 & 0.08 \\
\hline
\end{tabular}

Research and production test on feeding of linen cake (norm of $1 \mathrm{~g}$ on $1 \mathrm{~kg}$ of alive weight with corresponding decrease of mass of concentrated forages) was carried out to stall the period within 120 days on the lactating cows - firstcalf heifers and bull-calves of red steppe breed on sagination at the age of 14.5 months.

On termination of experiment, it was established that feeding of linen cake within 120 days did not reveal reliable distinctions on biochemical composition of blood between experimental and control group of cows - analogs of red steppe breed, except in the content of carotene. On termination of the experiment, its quantity in the blood of the experimental group was $25 \%$ higher than in the control. The content of heavy metals in the blood of cows of the experimental group decreased: lead by 1.6 ; zincum by 2.0 ; copper by 1.2 ; nickel by 2.3 and iron by 1.4 times. The concentration of heavy metals in milk of cows of control group noted in the beginning of the experiment and during the experiment did not change. At the end of the experiment, the blood of the experimental group contained zincum 1.8 times, copper 2.2 times, nickel 2.5 times, and prostaglandinums 2.1 times lower than at the beginning of the experiment (Table 3 ).

T a b l e 3. The heavy metal content in the milk of cows of red steppe species $(\mathrm{mg} / \mathrm{kg})$ in the experiment by feeding linseed meal.

\begin{tabular}{|l|l|c|c|c|c|}
\hline \multirow{2}{*}{ Heavy metals } & \multirow{2}{*}{ MPC } & \multicolumn{3}{|c|}{ Group $\mathbf{( M \pm ~ m )}$} \\
\cline { 3 - 6 } & & \multicolumn{2}{|c|}{ Control } & \multicolumn{2}{c|}{ Experienced } \\
\cline { 3 - 6 } & & $\begin{array}{c}\text { At the beginning } \\
\text { of the experiment }\end{array}$ & $\begin{array}{c}\text { On completion } \\
\text { of the experiment }\end{array}$ & $\begin{array}{c}\text { At the beginning } \\
\text { of the experiment }\end{array}$ & $\begin{array}{c}\text { On completion } \\
\text { of the experiment }\end{array}$ \\
\hline Copper & 1.0 & $0.75 \pm 0.02$ & $0.76 \pm 0.04$ & $0.78 \pm 0.05$ & $0.35 \pm 0.02$ \\
\hline Zinc & 5.0 & $4.54 \pm 0.16$ & $4.50 \pm 0.18$ & $4.60 \pm 0.15$ & $2.51 \pm 0.12$ \\
\hline Nickel & 0.1 & $0.25 \pm 0.04$ & $0.26 \pm 0.05$ & $0.28 \pm 0.08$ & $0.11 \pm 0.007$ \\
\hline Iron & 0.3 & $1.38 \pm 0.07$ & $1.39 \pm 0.06$ & $1.37 \pm 0.06$ & $0.65 \pm 0.02$ \\
\hline
\end{tabular}

On termination of the experiment, the analysis carried out on three bull-calves from each group showed that the content of highly hazardous metals $(\mathrm{Hg}, \mathrm{Pb}, \mathrm{Cd})$ and As was almost identical in products of slaughter of control and experimental groups and made: in a pulp $-0.02 \mathrm{mg} / \mathrm{kg}$ of hydrargyrum, 0.07 - cadmium, 0.08 -arsenic and 0.24 - lead. Concentration of zincum, copper, nickel and iron significantly went down (Table 4) respectively by 1.7, 2.2, 1.8 and 2.0 times. In internal organs (i.e. heart, lungs, liver and spleen), the greatest decrease was noted in liver and spleen. 
Use of linen cake positively affected the processing behaviour of milk of cows. In the bull-calves receiving linen cake, the quantity of protein in pulp of ink increased by $15.3 \%$, at the same time the amount of fat made $9.5 \%$ in comparison with monitoring. It is explained by high nutritiousness of linen cake, the contents in it are the irreplaceable amino acids, fat, macro- and microcells.

T a b l e 4 . The content of heavy metals in products of slaughter calves of red steppe breed.

\begin{tabular}{|c|c|c|c|c|c|c|c|c|}
\hline \multirow{3}{*}{$\begin{array}{l}\text { Products } \\
\text { of slaughter }\end{array}$} & \multicolumn{8}{|c|}{ Metals, mg/kg } \\
\hline & \multicolumn{2}{|c|}{ Zinc } & \multicolumn{2}{|c|}{ Copper } & \multicolumn{2}{|c|}{ Nickel } & \multicolumn{2}{|c|}{ Iron } \\
\hline & ${ }^{\star} \mathrm{C}$ & $\mathbf{O}$ & C & O & $\mathrm{C}$ & $\mathbf{O}$ & $\mathrm{C}$ & $\mathbf{O}$ \\
\hline Meat & $47.1 \pm 0.20$ & $27.3 \pm 0.21$ & $1.34 \pm 0.06$ & $0.6 \pm 0.03$ & $0.40 \pm 0.03$ & $0.22 \pm 0.01$ & $44.4 \pm 1.03$ & $22.3 \pm 0.54$ \\
\hline Heart & $9.4 \pm 0.17$ & $7.7 \pm 0.12$ & $2.3 \pm 0.09$ & $2.0 \pm 0.02$ & $0.34 \pm 0.01$ & $0.28 \pm 0.03$ & $2.1 \pm 0.09$ & $1.3 \pm 0.03$ \\
\hline Lung & $12.8 \pm 0.24$ & $10.1 \pm 0.16$ & $0.8 \pm 0.04$ & $0.4 \pm 0.03$ & $0.29 \pm 0.04$ & $0.14 \pm 0.01$ & $4.0 \pm 0.08$ & $3.2 \pm 0.05$ \\
\hline Liver & $28.2 \pm 0.24$ & $12.2 \pm 0.18$ & $2.1 \pm 0.10$ & $0.6 \pm 0.04$ & $0.59 \pm 0.02$ & $0.29 \pm 0.03$ & $38.6 \pm 0.72$ & $22.8 \pm 0.91$ \\
\hline Spleen & $28.8 \pm 0.22$ & $14.2 \pm 0.25$ & $2.5 \pm 0.11$ & $2.0 \pm 0.14$ & $0.80 \pm 0.02$ & $0.60 \pm 0.01$ & $42.0 \pm 2.02$ & $28.0 \pm 0.71$ \\
\hline MPC & \multicolumn{2}{|c|}{40.0} & \multicolumn{2}{|c|}{5.0} & \multicolumn{2}{|c|}{0.5} & \multicolumn{2}{|c|}{50.0} \\
\hline
\end{tabular}

Notes: ${ }^{\star} \mathrm{C}$ - control group, $\mathrm{O}$ - test-group.

Thus, researches showed that the suburban ecosystems of Volgograd are exposed to negative technogenic; the most dangerous toxicants for them are heavy metals.

Monitoring the content of heavy metals $(\mathrm{Cd}, \mathrm{Pb}, \mathrm{Hg}, \mathrm{Zn}, \mathrm{Cu}, \mathrm{Ni}, \mathrm{Fe})$ and arsenic in a trophic chain of three lactic breeds of cows and bull-calves during the pasturable and stall period (air, soil, water, a stern, an organism of cattle, milk and slaughter products) in suburban ecosystems of the southern industrial zone revealed excess of maximum concentration limits of heavy metals in the soil, in sterns of a winter diet and in sterns of a summer diet. In the conditions of a technogenesis of a residential suburb of Volgograd, cows of red steppe breed were steadier against the influence of adverse natural and anthropogenous factors. On chemical composition, the processing behaviour of meat and the results of its organoleptic assessment, the bull-calves of red steppe breed had the best indexes in comparison with the black and motley and red and motley breeds. In products of slaughter of these animals, the least content of the metals exceeding maximum concentration limit - nickel and iron was noted. The content of heavy metals in production of cattle breeding (milk and products of slaughter) was in direct dependence on the contents in sterns. The greatest pollution of forages was noted during the pasturable period. In the daily diet, the content of iron made 3 maximum concentration limits and nickel made four maximum concentration limits. Inclusion in diets of the lactating cows and bull-calves on sagination of linen cake improved the processing behaviour of milk and meat: milk contained $2.3 \%$ more sugar, SNF, on 2.4 - non-volatile solid; in meat, there was $15.3 \%$ more protein. Also, this sorbent allowed lowering the content of heavy metals in the organism and the products of cows and bull-calves of the experimental groups. 


\section{Conclusion}

In our research, new evidence on the state of the environment of a large industrial centre - the Volgograd-city was obtained. Based on the results of our research, we can make the following proposals:

- Due to the intensive technogenic pollution of residential suburbs of the industrial centres, it is necessary to monitor the forages consumed by animals and the productions of animal husbandry on the maintenance of I and II class of danger elements (Cd, $\mathrm{Pb}, \mathrm{Hg}, \mathrm{Zn}, \mathrm{Cu}, \mathrm{Ni}$ and $\mathrm{Fe}$ ).

- In the technologically contaminated areas, for the production of environmentally friendly products, it is advisable to breed the cattle breeds that are resistant to exposure to hazardous xenobiotics - heavy metals. Such species include red steppe.

- To reduce HMs in products of animal husbandry and to increase its quality under the technogenic pressure, it is necessary to include linen cake in the diets of cattle at the rate of $1 \mathrm{~g}$ on $1 \mathrm{~kg}$ of alive weight.

\section{References}

Belyaev, A.I. (2004). Development of methods for the rational use of resources, breed cattle for beef production in the Lower Volga region. An abstract of doctor of agricultural Science dissertation, Volgograd, Russian Federation.

Kaydulina, A.A., Pen'kova, I.N. (2011). Meat efficiency and environmental safety of cattle fattening in the industrial. Proceedings of the Lower Volga agrouniversity complex: Science and Higher Vocational Education, 2(22), 117-123.

López-Alonso, M. (2012). Trace minerals and livestock: Not too much not too little. ISRN Veterinary Science, 18. DOI: $10.5402 / 2012 / 704825$.

Osadchenko, I.M., Gorlov, I.F., Pen'kova, I.N. \& Rivnyak T.T. (2004). Patent RUS 2251450 29.03.2004. Moscow: R.F.

Pen'kova, I.N., Rivnyak, T.T., Onstratenko, N.V. (2005). Ecological aspects of milk production in a suburban area of Volgograd. Animal Husbandry, 6, 20-24.

Pen'kova, I. N., Mishina, O. Y., Onistratenko, N.V. (2013). Meat yield and mineral composition of muscle tissue of cattle fattening in the industrial. Proceedings of Nizhnvolzhskiy agrouniversity complex: science and higher vocational education (pp. 128-134).

Thornton, Ph. K. (2010). Livestock production: recent trends, future prospects. Philos Trans. R. Soc. Lond. B Biol. Sci., 365(1554), 2853-2867. DOI: 10.1098/rstb.2010.0134.

Wanapat, M., Kang, S., Khejornsart, P. \& Wanapat S. (2013). Effects of plant herb combination supplementation on rumen fermentation and nutrient digestibility in beef cattle. Asian-Australas. J. Anim. Sci., 26(8), 1127-1136. DOI: 10.5713/ajas.2013.13013.

Zelepukhin, A.G. \& Levahin V.I. (2000). Beef cattle. Orenburg, Russian Federation: Publishing House of the Orenburg State University. 